\title{
Comments
}

\section{RULE 10b-5: THE IN PARI DELICTO AND UNCLEAN HANDS DEFENSES}

Rule 10b-5, promulgated pursuant to the Securities Exchange Act of 1934, is today the most litigated portion of that Act. Because the rule protects a public interest broader than that of the individual litigants, the courts have allowed private actions to enforce the rule-liberally construing its terms whenever possible. Recently, however, two cases have retreated from this trend by refusing to bar the defenses of in pari delicto and unclean hands to private actions. This Comment traces the history and congressional purposes implemented by the federal securities laws to demonstrate that the refusal to bar these defenses in rule 10b-5 situations, where private actions are necessary to promote important public interests, actually hinders the objectives of the Securities Exchange Act.

Assume the following: Congress has promulgated a rule to regulate the securities market whose breakdown five years before had led to the greatest financial disaster the world had ever witnessed. The rule makes unlawful any use of the mails or facilities of interstate commerce as part of any fradulent act in connection with the purchase or sale of any security. Assume further that because of the great public interest to be served by the enforcement of the rule and the limited enforcement powers of congressional agencies, the courts have allowed private individuals to bring actions directly under the rule. Suppose a broker, in violation of this rule, informs his customer of significant new corporate developments in an attempt to increase his sales commissions. If the customer purchases stock on the basis of this information, should he be barred from suing the broker when this information proves to have been a deliberate fabrication? A critical issue then arises as to whether the courts should allow an action by the customer because his suit incidentally enforces a broad public interest. Or, should the courts recognize the common law defense in pari delicto and unclean hands?

These questions were presented in two recent decisions ${ }^{1}$ under rule $10 \mathrm{~b}-5^{2}$ of the Securities Exchange Act of $1934 .^{3}$ While judi-

1. Kuehnert v. Texstar Corp., 412 F.2d 700 (5th Cir. 1969); Wohl v. Blair \& Co., 50 F.R.D. 89 (S.D.N.Y. 1970).

2. 17 C.F.R. $\$ 240.10 \mathrm{~b}-5(1970)$. The rule provides:

It shall be unlawful for any person, directly or indirectly, by the use of any ineans of instrumentality of interstate commerce, or of the inails or of any 
cial construction has extended rule $10 \mathrm{~b}-5$ to a wide variety of fraudulent and deceitful practices, these two decisions have refused to bar the defenses of in pari delicto and unclean hands. Part I of this Comment examines the recent cases which have allowed the defenses of in pari delicto and unclean hands under rule 10b-5. Part II examines the purposes of the Securities Exchange Act of 1934 and the goals of rule $10 \mathrm{~b}-5$ and concludes that allowing the defenses hinders these purposes. Part III traces the origin, history, and scope of the defenses, arguing agamst their application under these fact situations and under rule $10 \mathrm{~b}-5$ actions in general.

\section{I}

THE JUDICIAL RESPONSE TO THE DEFENSES

Although more actions are brought under section $10(\mathrm{~b})$ than any other section of the Securities Exchange Act of 1934, the courts have only recently faced the question of whether defenses to private actions are consistent with the purposes of the Act. The first case appears to have been Hooper v. Mountain States Securities Corp. ${ }^{4}$ where the plaintiff brought an action for the allegedly fraudulent purchase by the defendant of shares in the plaintiff's corporation. The defendant contended that the corporation had issued shares in violation of the SEC registration requirements, misrepresenting to its transfer agent that the shares were exempt from registration. The Fifth Circuit, without explaining its ruling, denied the defense of in pari delicto. ${ }^{5}$ In a similar case, Cartier v. Dutton, ${ }^{6}$ the District Court for the Southern District of New York stated that it might under some circumstances sustain an unclean hands defense. ${ }^{7}$ It was not faced with the question, however, and did not consider it further. Thus, the defenses and the policies that bear on their validity in a rule $10 \mathrm{~b}-5$ action were not fully explored by any court until Kuehnert v. Texstar Corporation ${ }^{8}$ was decided. In Kuehnert, Rhame, Texstar's president, told his friend Kuehnert of the coinpany's secret oil discoveries and of his plans to acquire

facility of any national securities exchange,

(a) To employ any device, scheme or artifice to defraud,

(b) To make any untrue statement of a material fact or to omit to state a material fact necessary in order to make the statements made, im the light of the circumstances under which they were made, not misleading, or

(c) To engage in any act, practice, or course of business which operates or would operate as a fraud or deceit upon any person, in connection with the purchase or sale of any security.

3. Securities Exchange Act of 1934, 15 U.S.C. $\S \S 78$ a et seq. (1964).

4. 282 F.2d 195 (5th Cir. 1960), cert. denied, 365 U.S. 814 (1961).

5. 282 F.2d at 207.

6. 45 F.R.D. 278 (S.D.N.Y. 1965).

7. Id. at 280 .

8. 412 F.2d 700 (5th Cir. 1969). 
company stock. Rhame suggested that to benefit from the anticipated increases in the dividends and the market value of Texstar shares, he and Kuehnert should keep this information confidential and endeavor to buy enough stock to acquire working control of Texstar. Kuehnert, without disclosing this tip, bought a substantial amount of Texstar stock on margin. Rhame's representations were in large part false, ${ }^{9}$ and Kuehnert lost all his investment. He then sued Rhame alleging a violation of rule $10 \mathrm{~b}-5$. The trial court granted Rhame's motion for suminary judgment on the ground that Kuehnert himself had violated rule $10 \mathrm{~b}-5$ and therefore could not recover. ${ }^{10}$ The United States Court of Appeals for the Fifth Circuit affirmed. ${ }^{11}$

A short time later, the United States District Court for the Southern District of New York faced the same issue in Wohl v. Blair \& Co. ${ }^{12}$ A registered representative of Blair \& Co., a broker-dealer, told Wohl that he had favorable inside information regarding certain securities. Wohl purchased the securities through Blair \& Co. without disclosing the information; when it proved to be untrue, he suffered substantial losses. In the subsequent suit against the broker-dealer, the defendant's answer alleged the affirmative defenses of in pari delicto and unclean hands. ${ }^{13}$ Wohl inoved to strike the defenses, distmguishing Kuehnert on the grounds that affirmative defenses are not available to a broker-dealer who is not, in fact, an insider. ${ }^{14}$ The court, lowever, refused to recognize this technical distmction between one who is in fact an insider and one who merely purports to have inside information. The court held that a tippee ${ }^{15}$ who claims that he is fradulently in-

9. Id. at 702 .

10. 286 F. Supp. 340 (S.D. Tex. 1968).

11. Kuehnert v. Texstar Corp., 412 F.2d 700 (5th Cir. 1969).

12. 50 F.R.D. 89 (S.D.N.Y. 1970).

13. Id.

14. Officers and directors are insiders, so are substantial or controlling stockholders. Ross v. Licht, 263 F. Supp. 395 (S.D.N.Y. 1967). Beyond this, anyone may be au insider if he has "such a relationship to the corporatiou that he had access to information which should be used 'only for a corporate purpose and not for the benefit of anyone.'" Id. at 409.

15. A tippee, like an insider, is one who acquires inside information [Ross v. Licht, 263 F. Supp. 395, 410 (S.D.N.Y. 1967)] and is, by virtue of rule 10b-5, obliged to disclose the information before trading. In re Cady, Roberts \& Co., 40 S.E.C. 907 (1961). See SEC v. Texas Gulf Sulphur Co., 401 F.2d 833 (2d Cir.), cert. denied, 394 U.S. 976 (1968). The distinction between insiders and tippees seems to be drawu on the basis of the purpose behind disclosure of the information to the individual. Thus a tippee is the object of a "selective disclosure of material inside (nonpublic) informatiou for trading or other personal purposes," whereas the insider acquires the information for "purposes of the company (to which the information pertains)." A. BromBErG, Securities Law: FraUd-RULE 10B-5, § 7.5(2), at 190.7 (1969). Professor Loss has dubbed not only friends, but friends of friends as tippees. Cary, Israels \& Loss, Recent Developments in Securities Regulation, 63 CoLUM. L. REv. 856, 867 (1963). 
duced to purchase securities on the basis of what he erroneously believed to be inside information should be barred by the defenses regardless of the alleged source of his information. The court adopted a "caveat tippee" policy in following Kuehnert. ${ }^{16}$

Implicit in both Kuehnert and Wohl is the courts' determination that allowance of the defenses will provide a strong deterrent to the practice of accepting and trading upon tips of inside information. The tippee $^{17}$ is told that he acts at his peril. If the information is false, he is left with no legal recourse to recoup his loss. ${ }^{18}$ There is, however, a price for this deterrent: Kuehnert and Wohl insulate an insider from civil liability for misrepresentation under rule $10 \mathrm{~b}-5$, provided he gives the false information under the pretext that it is from an inside source. If his fraud is successful, the tippee is likely to be the only person injured and thus the only person with the standing and incentive to bring a civil action. ${ }^{19}$ If the tippee does in turn, pass the information along to others, then the tippee's tippees would also seem subject to the defenses if they are told the information is "inside" and trade before it is disclosed. The net effect is to remove the sanction of civil hability almost compltely from this type securities fraud.

Thus, a critical analysis of Kuehnert and Wohl must focus on the question of whether the purposes of the Securities Exchange Act of 1934 in general, and rule 10b-5 in particular, are better served by subjecting the insider to liability for his misrepresentation, or by denying the tippee relief if he accepts and trades upon supposedly inside information which later proves false.

16. The Wohl court wrote a short opinion, relying extensively on the reasoning of the Fifth Circuit in Kuehnert. The Wohl court analogized their tippee to Kuehnert and held that his " status as a tippee makes the defenses of unclean hands and in pari delicto available, their apphication rests with the discretion of the court.' " 50 F.R.D. at 92, quoting Kuehnert v. Texstar Corp., 412 F.2d 700, 704 (5th Cir. 1969).

17. For purposes of this discussion, the person passing along the false information is termed an "insider" while the recipient is termed a "tippee." This terminology is not, however, altogether accurate since a tippee who passed along false information on the assertion that it is "inside" would, under Wohl, be allowed to raise the in pari delicto and unclean hands defenses. See notes 14-16 supra and accompanying text.

18. On the other hand, if the information is true he may be subject to hability in favor of the person with whom he trades. See note 14 supra. The insider would, of course, still be subject to criminal and administrative penalities provided by the Securities Exchange Act.

19. If the information is false, the person who trades with the tippee will presumably realize an economic benefit and will, therefore, have neither standing nor incentive to sue. It is possible that the market activity caused by the tippee's trading will induce others to enter the market or affect their investment decisions to their detriment. They might conceivably have a cause of action against the insider, although no case has so held. 
II

THE OBJECTIVES AND ENFORCEMENT OF THE 1934 ACT

\section{A. Objectives of Rule $10 b-5$}

The major objective of the federal securities law is to provide protection to the investing public. ${ }^{20}$ The Securities Exchange Act of 1934 is more than a policy statement of Congress; its teeth are its in terrorein provisions extending beyond common law protection afforded investors. Section 10(b) of the Securities Exchange Act of $1934^{21}$ is a catchall antifraud provision giving the Securities and Exchange Commission (SEC) rule-making power to proscribe a wide variety of manipulative and deceptive securities practices which are not covered by other sections of the Act. Rule 10b-5, promulgated under this section, forbids a broad spectrum of fraudulent and deceptive practices. ${ }^{22}$ But, in line with the overall purpose of the Act, perliaps its most significant application has been the requirement of disclosure ${ }^{23}$ which demands that all parties to security transactions, whether or not they take place over impersonal exchanges, have relatively equal access to material information affecting the value of the security.

Neither section 10(b) nor rule 10b-5 expressly creates a right of action for an injured party. An implied right of action for violations of rule $10 \mathrm{~b}-5$ is, however, now well established, ${ }^{24}$ and the impled private action under rule $10 \mathrm{~b}-5$ has greatly facilitated enforcement of

20. The Supreme Court maintains that "Congress intended ... securities legisIation 'enacted for the purpose of avoiding frauds' to be construed not technically and restrictively, but flexibly to effectuate its remedial purpose." SEC v. Capital Gains Research Bureau, 375 U.S. 180, 195 (1953).

21. 15 U.S.C. $\$ 78 \mathrm{j}(1964)$.

22. Though rule $10 \mathrm{~b}-5$ was rarely used in its early years, it is now the basis for approximately one-third of all cases, public and private, brought under the federal security laws and generates almost as much litigaton as all the other antifraud provisions combinied. A. Bromberg, supra note $15, \S 2.5(6)$, at $45-46$. By far the preponderant number of current $10 \mathrm{~b}-5$ cases consist of private actons.

23. A principal objective of the Securities Exchange Act of 1934-as well as the Securities Act of 1933-is full disclosure. See H.R. REP. No 1383, 73rd Cong., 2d Sess. $6-7$ (1934); H.R. REP. No. 85, 73rd Cong., 1st Sess. 1-9 (1933). See generally Sommer, Rule 10b-5: Notes for Legislation, 17 W. RES. L. REv. 1029, 1035 (1966). The modern emphasis of rule $10 \mathrm{~b}-5$ focuses upon increasing corporate disclosure. A. Bromberg, supra note 15, $\$ 12.3$, at 269; Fleischer, Controls on Insider Trading, 34 U. Mo. K.C.L. Rev. 210, 220 (1966). And, while no case has held that rule 10b-5 was violated by simple nondisclosure, there is dicta to that effect. See, e.g., List v. Fashion Park, Inc., 340 F.2d 457, 461-62 (2d Cir.), cert. denied, 382 U.S. 811 (1965).

24. The first case to so hold was Kardon v. National Gypsum Co., 69 F. Supp. 512 (E.D. Pa. 1946). The private right of action is now recognized by all circuits. $3 \mathrm{~L}$. Loss, Securities Regulation 1763-64 (1961, Supp. 1969). The United States Supreme Court has never passed on the issue. Cf. J.I. Case Co. v. Borak, 377 U.S. 426 (1964). 
the rule. Combining this rationale with a reading of congressional intent to protect investors, ${ }^{25}$ the federal courts have hiberally construed the requirements of recovery under rule $10 \mathrm{~b}-5$. Thus rule $10 \mathrm{~b}-5$ does more than provide a federal forum for actions to remedy fraud in securities dealings. Under the rule, the plaintiff is not hindered by many of the substantive and procedural requirements of proving common law fraud or deceit. ${ }^{2 B}$ And while it has been held that the "purpose of the Securities Exchange Act is to protect the innocent investor, not one who loses his innocence and then waits to see how his investment turns out before he decides to invoke the provisions of the Act," ${ }^{27}$ at present almost no amount of gullibility, ${ }^{28}$ lack of diligence in inquiring, ${ }^{20}$ or blindness to what is going on $^{30}$ has necessarily disqualified a plaintiff from succeeding under rule $10 \mathrm{~b}-5$. Nor does one lose the protection of the Act because he becoines involved to soine extent in the illegality of the securities sale. ${ }^{31}$

Kuehnert and Wohl run counter to this trend in the law under

25. See Jordan Bldg. Corp. v. Doyle, O'Connor \& Co., 401 F.2d 47 (7th Cir. 1968); cf. J.I. Case Co. v. Borak, 377 U.S. 426, 432 (1964) (private right of action under section 14(a) of the Securities Exchange Act of 1934 because the Act is for "the protection of investors").

26. At common law, to establish fraud or deceit, an aggrieved plaintiff was required to prove that the defendant had made a false representation of a material fact with knowledge (scienter) of its falsity for the purpose of inducing the plaintiff to rely on it and that the plaintiff rehed on it to his detriment. Under rule 10b-5, however, the plaintiff need only establish that a false representation was made through the mails or through interstate commerce in connection with the purchase or sale of any security, and that he was damaged either as a purchaser or as a seller of the security. Speed v. Transamerica Corp., 99 F. Supp. 808, 831 (D. Del. 1951). For a further comparison of the two types of fraud, see 3. L. Loss, supra note 24 at 1445-74.

27. Royal Air Properties v. Smith, 312 F.2d 210, 213-14 (9th Cir. 1962).

28. E.g., Surowitz v. Hilton Hotels Corp., 342 F.2d 596 (7th Cir. 1965), rev'd on other grounds, 383 U.S. 363 (1966). "[T]he policy of the federal securities laws is to protect investors, including the uninformed, the ignorant and the gullible." 342 F.2d at 602 .

29. E.g., Rogen v. Ilikon Corp., 361 F.2d 260 (1st Cir. 1966).

30. Royal Air Properties v. Smitl, 333 F.2d 568 (9th Cir. 1964).

31. Can-Am Petroleum Co. v. Beck, 331 F.2d 371, 373 (10th Cir. 1964), In Beck, the corporation solicited the plaintiff as a potential investor $\dot{m}$ a plan to raise eapital in violation of the Securities Act. The court correctly refused to apply the defense of in pari delicto to a "naive" businesswoman whose relationship as an investor bccame adulterated when she actively, but innocently, assisted in selling shares. The court explained:

In such event, since the policy of the law designed to diseourage illegal agreements comes in conflict with that policy which demands the effective enforcement of the Corporate Securities Act, the law differentiates the guilt of the parties, because refusal of relief to the less culpable would involve harmful effects wholly out of proportion to the requirements of imdividual punishment or the discouragement of illegal contracts.

Id. at 373, citing $6 \mathrm{~S}$. Williston, A TREATISE ON THE LAW of CONTRACTS $\$ 1789$, at 5085-86 (1938). Miller v. California Roofing Co., 55 Cal. App. 2d 136, 143.44, 130 P.2d 740, 745 (1st Dist. 1942). 
rule 10b-5. This divergence from the liberal trend of decisions may be explained by the dilemma presented by the facts of Kuehnert and Wohl. Rule 10b-5 sanctions both misrepresentations of material facts concerning the value of securities and trading on the basis of material undisclosed information. ${ }^{32}$ The former goal would have been advanced if Kuehnert and Wohl had demed the in pari delicto and unclean hands defenses; allowimg the defenses arguably advanced the latter goal by apparently deterring trading on the basis of material undisclosed imformation. Although the plaintiffs in Kuehnert and Wohl did not in fact trade on such information, allowing them a cause of action would, in effect have given them an imsurance policy against false tips. ${ }^{33}$ In theory then, tippees would be less reluctant to act on the basis of inside tips.

In allowing the defenses, the courts in Kuehnert and Wohl made the pohicy decision that the deterrent value of denying the tippee his insurance policy was more beneficial to achieving the purposes of rule $10 \mathrm{~b}-5$ than adding the sanction of civil liability to the insider's misrepresentation. Had the courts carefully analyzed the problem, however, they would have found strong support for the opposite conclusion.

\section{B. The Necessity for Private Action}

Encouraging private actions to deter rule $10 \mathrm{~b}-5$ violations even where the plaintiff may have violated the rule himself has analogous precedent in other areas of the law where public policy lias encouraged private actions enforcing a public interest even though granting a windfall to the wrongdoing plaintiff. For example, the defenses of in pari delicto and unclean hands cannot be raised in suits alleging violations of the federal antitrust laws. In Perma Life Mufflers, Inc. v. International Parts Corp.,$^{34}$ the Supreme Court explained:

We have often indicated the inappropriateness of invoking broad common law barriers to relief where a private suit serves important public purposes .... The antitrust laws are best served by ensuring that the private action will be an ever-present threat to deter anyone contemplating business behavior in violation of the antitrust laws. The plaintiff who reaps the reward of treble damages inay be no less morally reprehensible than the defendant, but the law encourages his suit to further the overriding public policy in favor of competition. A more fastidious regard for the relative moral worth of the parties would only result in seriously undermining the usefulness of the private action as a bulwark of antitrust enforcement. ${ }^{35}$

32. SEC v. Texas Gulf Sulphur Co., 401 F.2d 833 (2d Cir. 1968).

33. The Kuehnert court emphasized this point. 412 F.2d at 704.

34. 392 U.S. 134 (1969).

35. Id. at 138. 
Kuehnert and Wohl noted that the public policy of disallowing the unclean hands defense in antitrust actions is somewhat limited in its importance since true co-conspirators may be deprived of recovery even under the Sherman Act. ${ }^{36}$ In neither case, lowever, were the parties co-conspirators in any sense, due to their lack of common intent. ${ }^{37}$

The Fifth Circuit further stated that the degree of public interest in preventing securities violations is not comparable to that evidenced by the antitrust treble damage provisions, and that there is not sufficient public interest in disallowing the defense wlien the only question before the court is an accounting between joint conspirators. ${ }^{38}$ The "not sufficient public interest" characterization of the Kuehnert and Wohl cases is extremely short-sighted. In the first place, if the court's conclusion is based on the determination that effective enforcement of the antitrust laws is more important than effective enforceinent of the securities laws-a questionable position at best-there is no such indication in the opinions. Second, others can be injured if their investment decisions are influenced by the narket activity caused by the tippee's trading. Thus the investing public and not just the "joint conspirators" is involved. Finally, public confidence in an honest securities marketplace is endangered whenever there are fraudulent activities, even if the accounting of only one investor is involved.

There may be even more compelling reasons supporting the argument that the need for private actions is greater in the rule $10 \mathrm{~b}-5$ actions than in antitrust suits. The effects of antitrust violations often manifest themselves in the market in which they operate and, when successful, usually have observable indications of that illegal behavior, such as increased concentration ratios, uniform prices, and excessive profits. In cases of fraud involving transactions on the open mar-

36. 15 U.S.C. $\$ \S 1$ et seq. (1964). In antitrust, the courts have distinguished between the defenses of unclean hands and in pari delicto. The defense of unclean has been barred in this area since 1951. Simpson v. Union Oil Co., 377 U.S. 13 (1964); Kiefer-Steward Co. v. Joseph E. Seagram \& Sons, 340 U.S. 211 (1951). In Perma Life, the Court extended the bar to in pari delicto in a fact situation where the plaintiff was a passive participant in the antitrust violation, but the Court expressly did not rule on the situation where the plaintiff actively supports, formulates and encourages the continuation of the defendant's illegal scheme. 392 U.S. at 140. Thus there are two possible interpretations of Perma Life. The narrowest would permit the defense of in pari delicto only when the plaintiff and the defendant are actually co-participants to the same degree in the same illegal transaction. This appears to have been the interpretation of the majority opinion in Kuehnert, adopted by the Wohl court, which cited Perma Life as support for the position that a true co-conspirator may be deprived of recovery even under the Sherman Act. 412 F.2d at 703. A broader reading of the Perma Life deeision is sought by the Kuehnert dissent which cited the case as support for the elimmation of the defense of in pari delicto in private attorney general suits enforcing federal statutory regulations. Id. at 706.

37. See text accompanying notes 80-81 infra.

38. 412 F.2d at 703. 
ket, there is generally little or no external indication of the illegal transaction. The investing public is unlikely to know of any fraud or insider activity that affects the market. There could be any number of reasons why an individual's stock declines in value,$^{39}$ most of which are unrelated to any manipulative or deceptive devices. Antitrust violations, therefore, are more likely to come to the attention of the public agencies charged with the responsibility of enforcement.

The problem of discovering fraud is illustrated by comparing rule $10 \mathrm{~b}-5$ cases with cases arising under the SEC rules governing disclosures in proxy statements. For example, to support its fimding that private actions were necessary in suits for violation of the SEC rules governing disclosures in proxies, the Court in J.I. Case Co. v. Borak ${ }^{40}$ stressed the administrative inability of the SEC to examine the various facts presented in proxy statements. ${ }^{41}$ The SEC is more likely to detect proxy violations, lowever, and bring actions on its own behalf, since affirmative representations are made in writing to the public. Any inability of the Commission could conceivably be cured by a well financed and well staffed SEC. In contrast, it is questionable whether any commission could be sufficiently staffed to discover the more remote and transitory manipulative or deceptive devices used in violations of rule $10 \mathrm{~b}-5$. Therefore, in rule $10 \mathrm{~b}-5$ cases, private suits are even more necessary for enforcement than in the proxy cases, where the better reasoned opinions deny the in pari delicto and unclean hands defenses. ${ }^{42}$

39. See H. ManNe, Insider Trading and the Stock Market 163-66 (1966). Manne lists several major discoverable events that generally trigger large changes in the prices of a company's stock. The problein is, however, connecting every insider and his friends, relatives, and acquaintances who get a wimdfall gain in the stock market with prior inside knowledge of these events.

40. 377 U.S. 426 (1964).

41. Id. at 429 .

42. The cases are split as to whether the in pari delicto and unclean hands defenses should be allowed in proxy violation cases. In Guadiosi v. Mellon, 269 F.2d 873 (3d Cir.), cert. denied, 361 U.S. 902 (1959), plaintiff violated proxy rules by intimidating proxy holders, and was therefore barred from recovery on his allegation that defendants improperly used corporate funds, which likewise constituted a violation of the proxy rules. Id. at 879-82. Thus Mellon ignores the fact that the proxy rules are to protect the shareholders in favor of the rationale that a court should not jeopardize its integrity by aiding a wrongdoer. In so doing, the court, in effect, promotes the exact injustice against which Professor Chaffee warns: That the concentration of judges on the cleau hands maxin sometimes does harm by distracting their attention froin the basic policies whicls are applicable to the situation before them. Chafee, Coming Into Equity with Clean Hands, 47 Mich. L. REv. 1065, 1092 (1949) (Part II). See notes 77-79 infra and accompanying text.

To the same effect, see Studebaker Corp. v. Allied Prod. Corp., 256 F. Supp. 173 (W.D. Mich. 1966). Contra, Union Pac. R.R. v. Chicago \& N.W. Ry., 226 F. Supp. 400 (N.D. Ill. 1964):

[The defense] would produce the illogic of leaving the shareholders unprotected when they have been doubly misled, stultifying the underlying purpose 
Judicial discretion in allowing the defense might appear to be the most flexible alternative since the court could evaluate and compare the plaintiff's wrongdoings to those of the defendant. The court could also determine the degree of injury to the public and decide which of the two parties before the court should be punished for that injury. The value of this approach is more apparent than real, however. A plaintiff who may be at fault to some degree cannot be expected to assume the expense of bringing an action and the risk of exposing himself to potential liability unless there is a strong indication that the law will offer the appropriate encouragement by barring the defenses. This is particularly important in rule $10 \mathrm{~b}-5$ violations, since it is relatively easy to acquire the status of tippee, often as a result of a sudden or accidental occurrence. Moreover, the Kuehnert court made no effort to adhere to historical standards for the application of the defenses of either unclean hands or pari delicto, ${ }^{43}$ persons who may have acquired the status of tippee may be wise not to expose their own potential liability in any incidental effort to serve the public interest by bringing an action against a person who is unequivocally guilty of insider abuses.

Thus it would appear that both Kuehnert and Wohl seriously underestimated the need of private actions as a necessary link in rule 10b-5 sanctions against misrepresentations by an insider. Without the sanction of civil liability, the insider is likely to go undetected and be left to practice his deceit again, with the incentive provided by the knowledge that lie is now virtually immune to civil hability for his violations of rule $10 \mathrm{~b}-5$.

\section{Deterring Tippee Trading}

The courts' willingness to allow the in pari delicto and unclean hands defenses is based upon more than its finding that no important public policy would be served by holding the insider liable. In fact, the courts tacitly concede that this, without more, would not be suffi-

of the national securities laws. Where a public interest is at stake, above the interests of the parties themselves, the proteetion of that paramount interest overcomes the judicial reluctance to assist a wrongdoer.

Id. at 410. See also the cases collected in $2 \mathrm{~L}$. Loss, supra note 24, at 955-56. The better rule with regard to proxy requirements would be to disallow the defense. This would promote the protection of the shareholders which is in keeping with the underlying purposes of the securities law. Courts do not lose integrity in aiding a wrongdoer if they thereby promote the purposes of the law. The shareholders would be helped because the litigation among the parties would alert the shareholders to the actual situation and give them more information which they could use to make rational decisions concerning the use of their proxies. Also the fear of litigaton would force the parties to adhere more strictly to the proxy.rules.

43. See text accompanying notes $58-70$ infra. 
cient to allow the insider to escape liability for his misrepresentation. The courts conclude, however, that barring the defenses would deter tippee trading and thus, in the long run, would better advance the public protection goal of rule $10 \mathrm{~b}-5 . .^{44}$ The importance of tippee motivation to buy or sue was neglected in the court's analysis.

Although tippee trading such as the kind that existed in $S E C v$. Texas Gulf Sulphur Co. ${ }^{45}$ is fairly easy to detect, less spectacular cases may be nearly impossible to uncover without extremely costly and undesirable federal invasions of privacy. Computers might simplify the tasks of associating dramatic changes in security prices with insiders, their friends, and acquaintances, ${ }^{46}$ but even this kind of policing would not prove that any profits were of the illegal variety. Moreover, since rule $10 \mathrm{~b}-5$ is applicable to purely private transactions as well as to transfers on the public exchanges, the extent of federal policing necessary to prevent frauds would be simply intolerable. ${ }^{47}$ The SEC cannot be expected to dissipate its energies chasing down a multitude of disconnected two party transactions, and there is little indication that Congress even intended that it should do so. Kuehnert and Wohl concluded that sanctions could best be provided by forcing the tippee to act at his peril. ${ }^{48}$

It is questionable, however, whether barring the tippee's action agaimst the insider will effectively provide the deterrence the courts assuined that it would. It is unlikely that the tippee would be deterred from using information gamed from an insider by the knowledge that he could not recover from the insider. In most instances, tippees will lave taken the tip from someone they trust, and therefore will not doubt the person's word. ${ }^{49}$ The tippee just wants to make money and does not think of possible adverse consequences.

44. The Wohl court expressly stated that "one possible solution may be the adoptiou of a form of 'caveat tippee' policy." 50 F.R.D. at 93.

45. 401 F.2d 833 (2d Cir.), cert. denied, 394 U.S. 976 (1968). Criticizing the Texas Gulf Sulphur decision see H. MANNE, supra note 39, at 45. See generally Comment, A Suggested Locus of Recovery in National Exchange Violations of Rule 10b-5, 54 CoRnelr L. Rev. 306 (1968).

46. See Cary, Israels \& Loss, supra note 15, at 867.

47. See generally, Elsen, Securities Law Investigations, in Revdew of SEcurities Regulations 875 (1969); Loomis, Enforcement Problems Under the Federal Securities Laws, 14 Bus. LAw. 665 (1959).

48. See note 52 infra.

49. The Kuehnert record shows the great amount of trust that uusophisticated investors often have in people who hold high positions in corporations, sucli as presidents and brokers. The following questioning of Kuehnert was recorded:

Q. You read it (the official prospectus) and didn't find anything about these two wells that Texaco and Humble were to drill?

A. No, sir.

Q. Didn't this give you some pause? 
In addition, the court failed to fully consider the effect of barring the defenses on encouraging tipping. There is a strong argument that the insider would reconsider making tips when he may have to guarantee them. Rejecting the defenses would tend to stop the dissemination of tips at their source, while allowing the defenses may result in more tips, since the tipper has nothing to lose by tipping. ${ }^{50}$

Thus, the court could have escaped it's dilemina by adopting a policy aimed at discouraging the giving of tips rather than the acceptance of tips-that is denying the tipper the benefit of the defenses. Such a policy would have been consistant with the policy of preventing misrepresentations as well.

\section{Equities}

Courts are often reluctant to bar defenses on the ground that a wrongdoer will be able to profit from his own wrongdoing and will have insurance against his co-conspirator in the event that the intended illegal operation is not profitable enough. ${ }^{51}$ This argument ignores the public interest involved in the plaintiff's action and the necessity of his action to protect it. For example, the courts have barred the defense in

A. No.

Q. Were you under the impression that-

A. This was a secret, I tell you. Mr. Rhame had impressed upon me the secrecy of this, of these wells being drilled.

Q. Which you had, nevertheless, disclosed to yonr broker?

A. Yes, because the broker and the stock house is, in my mind, the same as an attorney would be: You disclose things to him you wouldn't to other people.

Record at 58-59. Kuehnert v. Texstar Corp. 286 F. Supp. 340 (S.D. Tex 1968). The Kuehnert record further shows Kuehnert's faith in Rhame. Recounting the questioning of Kuehnert concerning information in the prospectus showing the company to be in poorer condition than Rhame had represented, Rhame told Kuehnert the trouble involved some uncollectable receivables:

Q. You mean you didn't sit down and try to add up to see if these things had been really the cause?

A. Huh-uh. I just had great faith in him. He was a good friend of mine, and I had no reason to doubt the man. I had no reason to doubt him. He was a very, very, very close friend.

Q. You had ouly known him a few months.

A. No.

Q Eight or ten months?

A About a year. About a year. But it was a very-some people you get to know very well very quickly. We were very close friends.

Record at 64-65.

50. If the information is true, he will have a satisfied customer and will be protected from those dealing with his tippee by the probleins of discovery and tracing. Sce note 49 supra and accompanying text.

51. Compare the objection in the Kuehnert majority discussion of the "danger" of giving a tippee "an enforceable warranty that secret information is true," 412 F.2d at 705, with Justice Black's observation in Perma Life that important public purposes should be encouraged even to the extent of "permitting the plaintiff to recover a windfall gain." 392 U.S. at 139. 
antitrust actions where the plaintiff is able, in fact, to recover treble damages and attorney fees ${ }^{52}$ on a recognition that the action is brought in the public interest. As a policy inatter, it is felt that it is inore desirable to effectuate the overriding congressional purpose than to deny a plaintiff a windfall. No treble dannage provisions exist with respect to rule 10b-5, however. ${ }^{53}$ Arguably, if the gain to the unethical plaintiff is any criteria, then the courts should be less reluctant to bar the defenses in actions under rule $10 \mathrm{~b}-5$ where the plaintiff is able only to recover actual dainages.

In other situations such as those involving fraudulent conveyances and inortgages, the courts have rejected the in pari delicto and unclean hands defenses where defendants have used undue influence in exploiting a confidential relationship. ${ }^{54}$ By allowing the defense in cases like Kuehnert and Wohl, the courts are actually helping one party wrong the other. This is directly contrary to one of the inajor purposes of the defenses, which is to discourage such wrong doing. ${ }^{55}$ The insider is given free rein, for he can give out information indiscriminately without regard to its truthfulness; as long as the tippee does not disclose, the insider is immune from civil liability. ${ }^{56}$

This rule allows the insider to manipulate the stock for his own profit in various ways. He can unload his own shares if he thinks the price might go down or tell some of his friends to do so, while the tippee has supported the inarket for the stock, perhaps even allowing the insider to make a profit. The insider could obtain control of the company through the use of dupes such as Kuehnert. Insiders could act for the company by getting the price of the stock up to obtain a better position for the stock in an upcoming merger. Or, they could injure someone financially out of spite. Rule $10 \mathrm{~b}-5$ is designed to protect unsophisticated investors like Kuehnert from unscrupulous insiders like Rhame. The Kuehnert and Wohl decisions achieve the opposite result.

52. Private actions for such damages are authorized by the Claytou Act $\S 4,15$ U.S.C. $\$ 15$ (1964).

53. Section 28(a) of the 1934 Act [15 U.S.C. $\$ 77 b b$ (1964)] limits damages to "actual damages" and the courts will disallow any punitive damages under rule 10b-5. Pappas v. Moss, 257 F. Supp. 345, 364 (D.N.J. 1966); Meisel v. North Jersey Trust Co., 216 F. Supp. 469 (S.D.N.Y. 1963). Section 28(a) also states that the Act creates additional, rather than exclusive remedies. 15 U.S.C. $\$ 77 \mathrm{bb}$ (1964). In Green v. Wolf, 406 F.2d 291 (2d Cir. 1968), the Second Circuit decided that punitive damages were not available since their imposition is not required as a deterrent to $10 \mathrm{~b}-5$ violations, since in these cases "it is possible that corporations and even other individuals . . . would be subject to crushing liabilities simply on the basis of actual damages . . . ." Id. at 303.

54. See 3 J. Pomeroy, EoUTty JURISPRUdence $\$ 940,942,956$ (5th ed. 1941).

55. See notes 75-76 infra and accompanying text.

56. See notes 17-19 supra and accompanying text. 
III

MISAPPLICATION OF THE DEFENSES IN KUEHNERT AND WOHL.

In Kuehnert and Wohl, the courts allowed the defenses of unclean hands and in pari delicto to bar actions brouglit under rule $10 \mathrm{~b}-5 .{ }^{57}$ An analysis of the origin, history, and scope of the two defenses demonstrates that they are not applicable in the fact situations presented by the two cases.

\section{A. Early History}

The origin of the unclean hands doctrine, according to Pound, ${ }^{58}$ can be traced to 1728 when a barrister of the Middle Temple, Richard Francis, published the first edition of Maxims of Equity. ${ }^{50}$ His Maxim II is "He that hath committed (an) imequity shall not have equity." 60 This maxim was the conclusion gleaned from Francis" analyses of nine cases. ${ }^{61}$ His conception of the maxim was narrowly postulated-"the mequity must liave been done to the defendant himself." ${ }^{22}$ The maxim as it is know today was first formulated in Dering v. Earl of Winchelsea. ${ }^{63}$ In that case, a collector of customs had given three separate bonds to the Crown for perforinance of his duties. The collector's brother was the only bondsman sued and he asked for contribution from the other bondsmen. The defense raised by the other bondsmen was that he had encouraged his brother in gaming and other irregularities when he must have known that his brother was dipping into public funds, simce he had no fortune of his own. The court rejected the defense, stating:

It is argued that the author of the loss shall not have the benefit of a contribution; but no cases have been cited . . . nor any principle .... It is not laying down any principle to say that his ill conduct disables him from having any relief in this Court. If this can be founded on any principle, it must be, that a inan must come into a Court of Equity with clean hands; but when this is said, it does not mean general depravity; . . . in a legal as well as in a moral sense, the companion, and perhaps the conductor, of [the collector]

57. These defenses are not mentioned in the Federal Securities laws. See H.R. REP. No. 1383, 73rd Cong., 2d Sess., 6-7 (1934); H.R. ReP. No. 85, 73rd Cong., 1st Sess. 1-9 (1933). See generally Sommer, supra note 23, at 1035.

58. Pound, On Certain Maxims of Equity, in Cambridge Legal Essays 259, 263-64 (1926).

59. R. Francis, Maxims of Equity (1728).

60. Id. at 7 .

61. See Chafee, Coming into Equity with Clean Hands, 47 MicH. L. REv. 877, 881-82 (1949) (Part I).

62. R. FrancIS, supra note 59, at 7 n.(a), citing Jones v. Lenthal, 22 Eng. Rep. 739 (Ch. 1669).

63. 29 Eng. Rep. 1184 (Ex. 1787). 
may be said to be the author or the loss, but to legal purposes, [the collector] himself is the author of it; and if the evil example of [his brother] led him on, this is not what the Court can take cognizance of. ${ }^{64}$

This and several similar early cases permitted the defense only when a wrong was done directly to the defendant by the plaintiff. ${ }^{65}$

In pari delicto is both a subdivision of the equitable maxim that "he who comes into equity must coine in with clean hands," and a separate common law rule. ${ }^{66}$ In a technical sense, in pari delicto apphes only to illegal or fraudulent conduct in which both parties actions are equally repreliensible. ${ }^{67}$ The reason behind the rule is well stated by Lord Mansfield in Holman v. Johnson: ${ }^{88}$

No court will lend its aid to a man who founds his cause of action upon an immoral or an illegal act. . . . It is upon that ground that the Court goes; not for the sake of the defendant, but because they will not lend their aid to such a plaintiff. So if the . . . defendant was to bring his action against the plaintiff, the latter would then have the advantage of it . . . .99

The unclean hands doctrine in equity encompasses the equitable aspects of the in pari delicto defense law; if both parties are equally reprehensible, the court will not aid one at the expense of the other. ${ }^{70}$

\section{B. The United States and Modern Interpretation of the Defenses}

In the United States, the unclean hands defense has assumed various forms in addition to that developed through its historical application. Some courts interpret it narrowly. These courts allow the defense only when both parties have at some point a mutual intent to commit the same wrong; ${ }^{71}$ one who has participated in an unlawful

64. Id. at $1184-85$.

65. See, e.g., Harrington v. Bigelow, 11 Paige 349 (N.Y. Ch. 1844); Weakley v. Watkins, 26 Tenn. 290 (1846). In 1797, for the first time, though not phrased in terms of clean hands, the doctrine was extended beyond the situation where the plamtiff's conduct is directly harmful to the defendant. The Chancellor denied aid to parties who acted illegally or immorally, even though the illegal or immoral conduct was not between the parties themselves. Chafee, supra note 61, at 883. Lord Kenyon, in the legendary Highwaymen's Case, [Everet v. Williams, discussed in 9 I.Q. Rev. 197 (1893)] said he had heard of a bill in chancery "to obtain an account of profits of a partnership trade carried on at Hounslow, but when it appeared that the trade was taking the purses of those who travelled over the heath, the court would not endure the bill." Quoted in Chafee, supra at 883.

66. See 2 J. POMEROY, supra note 54, §§ 397-98; 3 id. § 947.

67. See 3 id. $\$ 942$.

68. 98 Eng. Rep. 1120 (K.B. 1775).

69. Id. at 1121 .

70. See 3 J. POMEROY, supra note $54,8940$.

71. See, e.g., Cohn v. Pitzele, 117 Ill. App. 342 (1904), aff'd, 217 Ill. 30, 75 N.E. 392 (1905); Mason v. Carrothers, 105 Me. 392, 74 A. 1030 (1909); Kahn v. Walton, 46 Ohio 195,20 N.E. 203 (1889). 
undertaking cannot recover from his accomplice for injuries incurred in their joint endeavor. ${ }^{22}$

Other courts apply it inore liberally to bar a wrongdoer's recovery on a slowing that he is guilty of unlawful conduct that is in some way connected to his loss. ${ }^{73}$ The courts often deny recovery where fraud, illegality, or unconscionable conduct on the part of the plaintiff is disclosed. ${ }^{74}$ The reasoning behind the broader application of the doctrine is that the courts did not want to be used in any way to aid the wrongdoer in his illegal or immoral design. By denying the wrongdoer use of the courts to further his scheines it was hoped he would be deterred. $^{75}$ Public policy considerations in favor of common honesty lie at the base of this broader clean hands rule. It is the promotion of this public interest and not the protection of the defcndant wlio may be a wrongdoer which supports the availability of the defense.

Two reasons have often led courts to reject the defense even though the plaintiff had unclean liands. First, some courts have applied the policy that a party less at fault is not equally unorally tainted and therefore deserves the aid which the courts can give. ${ }^{78}$ Second, and inore important, some courts have disregarded the defense when to do so would be in the public interest. ${ }^{77}$ Many courts, lowever, never reacli the basic policy considerations of the cases before them. Professor Chaffee states:

72. 2 J. Pomerox, supra note 54, § 399; Annot., 4 A.L.R. 44, $62-64$ (1919).

73. See, e.g., Danciger v. Stone, 187 F. 853 (E.D. Okla. 1909); Baker v. Grand Rapids, 142 Mich. 687, 106 N.W. 208 (1906). See also Whelden v. Chappel, 8 R.I. 230 (1865) (common law case); Annot., supra note 72, at 104-05.

74. See Prineau v. Granfield, 193 F. 911, 913 (2d Cir. 1911); Hourz v. Hellman, 228 Mo. 655, 128 S.W. 1001 (1910).

75. 2 J. POMEROX, supra note $54, \S 398$.

76. E.g., Isaacson v. Isaacson, 28 N.Y.S.2d 517, 522 (Sup. Ct. 1941); 3 J. РомEROY, supra note 54, § 942.

77. E.g., Perma Life Mufflers, Inc. v. International Parts Corp., 392 U.S. 134 (1967); Precision Instruments Mfg. Co. v. Automotive Maintainence Mach. Co., 324 U.S. 806 (1945); Republic Molding Corp. v. B.W. Photo Util., 319 F.2d 347 (9th Cir. 1963). An example of the application of this rationale is found in Starke's Ex'rs v. Littlepage, $25 \mathrm{Va}$. (4 Rand.) 368 (1826). $A$ brought an action against $B$ to recover slaves who had been purchased by $A$ 's testator at a sheriff's sale pursuant to an execution against $B$. $A$ pnrchased the slaves with inoney provided by $B$ in order to defraud $B$ 's creditors. $B$ retained possession of the slaves under the pretext of hire. The appellate court reversed the lower court decision for $B$ :

[In pari delicto] operates only in cases, where the refusal of the Courts to aid either party .... takes away the teinptation to engage in contracts ... violating the policy of the laws. [Where the parties are in pari delicto the courts will] interfere actively in favor of plaintiff where such interfercnce promotes effectively the policy of the laws.

Id. at 372. Here, the public intertest in protecting creditors prevailed over the public interest in upholding an agreenent which was taintcd with iminorakity. 
[T] he concentration of judges on the clean hands maxim sometimes does harm by distracting their attention from the basic policies which are applicable to the situation before them. The matrimonial suits are a notable example of this bad tendency . . . . [T] he maxim also does harm by making some courts oversensitive to the ethical conduct of the plaintiff. The copyright cases illustrate this excessive rightousness . . . . ${ }^{79}$

\section{Recent Application of the Defenses}

The foregoing discussion indicates that the defenses might be allowed in rule 10b-5 actions under one or more of the following sets of circumstances: One, when the plaintiff's wrong occurred in the saine transaction from which he is asking relief and the wrong was done directly to the defendant; this is the strict or historical application of the defenses; two, when both parties have at some point a mutual intent to commit the same wrong; this is the modern application; three, when the plaintiff is guilty of immoral conduct or of breaking a rule that is connected to the loss in some way, though not necessarily connected with the defendant's misconduct.

Under the facts presented in Wohl and Kuehnert, the defenses were applicable under only the third of the three possible formulations, for neither Kuehnert nor Wohl had unclean hands under the historical or modern interpretations of the defenses. The Kuehnert court stated: "Kuehnert knowing nothing, concealed nothing, and hence did not defraud his vendors. Strictly speaking, he and Rhaine can not be seen as in pari delicto even as to intention, since, we will assume, Rhame's only matent was to defraud Kuehnert, while Kuhnert's was to defraud his vendors, a different group of persons." ${ }^{90}$ Similarly, in Wohl the defendant's only intention was fraudulently to induce Wohl to purchase more shares, while Wohl intended to defraud his vendors,

78. Chafee, supra note 42, at 1092. An example is Kellogg v. Kellogg, 171 Mich. 518, 137 N.W. 249 (1912), where a wife sued her husband for a divorce on grounds of extreme cruelty. The husband, by crossbill, asked for a divorce on the basis of his wife's extreme cruelty and adultery. In denying both spouses relief, Judge Stone said:

Divorce is a remedy for the innocent as against the guilty, and should not be granted where both parties are at fault. This is no more than the application of the equitable rule that one who invokcs the aid of a court must come into it with a clear conscience and clean hands.

Id. at 520,137 N.W. at 250 .

79. Chafee, supra note 42 , at 1092. Chafee refers to cases like Southey v. Sherwood, 35 Eng. Rep. 1006 (Ex. 1817), discussed in Chafee, supra at 1065 n.105, $1067 \mathrm{n} .117$ and accompanying text. The poet Southey wrote an obscene poem in his youth and did not want it published. Lord Eldon refused rehef in his suit against the publisher, assuming that the nature of the work might render publication a crime. As a result, it sold 60,000 copies. Chafee, supra note 61 , at 883,884 . See also Chafee, supra note 42 , at $1065-70$.

80. 412 F.2d at 704 . 
again a different group of persons. ${ }^{81}$ Therefore, neither Kuehnert's nor Wohl's conduct satisfied the requirement that the parties must have, at some point, a mutual intent to commit the same wrong.

Since both Kuehnert and Wohl set out to violate rule $10 \mathrm{~b}-5$, the third standard would encompass their conduct and support the application of the defenses in both cases. ${ }^{82}$ The Kuehnert decision, which was relied upon in Wohl, did not, however, cite any authority holding the third formulation of the defenses apphicable in rule 10b-5 cases. Instead, it relied on four cases which applied the mutual intent standard. In three of these cases, ${ }^{83}$ the parties had conspired to defraud a third person, but in each case one party liad ended up defrauding the other. The unclean hands defense in the modern mutual intent sense applied in each of these three cases, since the parties were at some point joint conspirators. The modern formulation would similarly loold the defenses available in the fourth case. ${ }^{84}$

Not only was case authority lacking in Wohl and Kuehnert for the application of the third formulation of the unclean liands defense, but also the generally recognized principles which ordinarily limit use of the defense strongly argue against its availability. As noted above, courts have traditionally given a paramount place to policy considerations when faced with the defense. ${ }^{85}$ They have disallowed the de-

81. "[T]he issue is whether a person who buys stock on the basis of inside information from his broker may be denied recovery fron his broker when it turns out that the latter actually did not have such inside information." 50 F.R.D. at 91.

82. The statutory phrase, "any nuanipulative or deceptive device" is broad enough to encompass conduct irrespective of its outcome. Courts in securities law cases have acted to eujoin potential frauds and have prosecuted attempted frauds without proof of actual loss. See, e.g., Hughes v. SEC, 174 F.2d 969 (D.C. Cir. 1949); Trussell v. United Uuderwriters, Ltd., 228 F. Supp. 757 (D. Colo. 1964).

83. Precision Instrument Mfg. Co. v. Autonıobile Maintenance Mach. Co., 324 U.S. 806 (1945) (plaintiff and defendant conspired to defraud a patent agency but the defendant used this fraud to cheat the plaintiff); New York Football Giants, Inc. v Los Angeles Chargers Football Club, 291 F.2d 471 (5th Cir. 1961) (parties conspired to defraud other football clubs by signing a player before he was an eligible draft choice, the player used this fraud to renege on his contract with the club); Ford v. Caspers, 42 F. Supp 994 (N.D. Ill.), aff'd, 128 F.2d 884 (7th Cir. 1941) (plaintiff aud defendant intended to cheat creditors; instead the defendant cheated the plaintiff).

84. Shinsaku Nagon v. McGrath, 187 F.2d 753 (7th Cir. 1951). In this case the plaintiff defrauded the Internal Reveuue Service by registering some of his property in his wife's name. The government tried to use this fraud to confiscate the property under the Trading with the Enenuy Act [50 U.S.C. App. $\$ 9$ (a) (1964)] to which his Japanese wife was subject. The court held that eveu though shares had been placed in the name of plaintiff's wife to secure tax advantages, plaintiff would not be denied relief in equity on the basis of the unclean hands doctrine where, in light of all pertinent facts, plaintiff's conduct could not be termed unconscionable or morally reprehensible, and where application of that doctrine would work forfeiture of plaintiffs property and result in injustice out of all proportion to the 75 dollar tax advantage which he allegedly secured. 187 F.2d at 758.

85. See notes 76-79 supra and accompanying text. 
fense in situations where a plaintiff's conduct technically fulfills the requirement for a plea of unclean hands ${ }^{86}$ if the defendant's wrong is more reprehensible than the plaintiff's in terms of either moral turpitude or of the amount of damage caused. ${ }^{87}$ In Kuehnert, Rhame, the corporation president, and in Wohl, the registered representative of the broker-dealers, knew that the information he disclosed was false, whereas Kuehnert, an unsophisticated investor, ${ }^{88}$ and Wohl, an average investor, ${ }^{89}$ may not have been aware of their duty to disclose before purchasing. ${ }^{90}$ The misconduct of Rhame as well as that of the broker manifested a conscious plan of initiating fraud; Kuehnert and Wohl were only followers. The misrepresentation of Rhame and the broker may have led to untold transactions and losses involving third parties as well as plaintiffs, ${ }^{01}$ whereas the only loss plaintiffs participated in causing was their own. Thus in Kuehnert and Wohl, the defendants, are clearly the inore reprehensible parties in terms of moral turpitude and damage caused. Further, as discussed earlier in this Comment, ${ }^{92}$ it is counterproductive to the objectives of the Securities Exchange Act of 1934 to allow the defenses in rule 10b-5 actions, especially in the fact situations presented in these cases. Both courts should, therefore, liave barred the defenses.

86. 3 J. POMEROY, supra note 54, § 942.

87. Id.

88. The transcript of the trial indicates that snch was probably the case:

Q. Do you have any conception at all, Mr. Kuehnert, of the obligations of an officer and director to his corporation and to his shareholders?

A. Not too much, no. I learned since, but I didn't know at the time.

Q. But he does have at least the duty of good faith and honesty, doesn't he?

A. Yes. I guess so.

Q. Do you think if Mr. Rhame was giving you secret information that he might have been violating this duty of good faith and honesty?

A. No, I didn't think that; it never entered my mind.

Record at 94.

Q. You just thought if you could use that secret information to your benefit, you might as well do it?

A. Yes. If I could make an investment and make a profit on the investment,

I wasn't doing anything wrong. It never entered my mind about his obliga-

tion to the company or anything like that.

Record at 88.

89. There is no indication that Wohl intended to acquire control of the company. His only motive was profit.

90. It would scem likely that insiders would be more informed by their legal counsel of the allowable limits of their conduct, while tippees are less likely to have the benefit of a corporate legal counscl. There are, in fact, conferences specifically directed toward educating lawyers on the ramifications of rule $10 \mathrm{~b}-5$ in New York and on the West Coast; each is reported to have 1,000 lawyers present. Financial World, Jan. 15, 1969 , at 28 , col. 1 .

91. Innocent observers of the stock market may have been induced to purchase stock on the belief that the increase in the price of the shares was attributable to economic reasons.

92. See pt. II supra. 


\section{CONCLUSION}

Since the courts have implied the right to bring a private action under rule $10 \mathrm{~b}-5$, the courts alone are able to establish the applicability of defenses to that action. The Supreme Court has in other relevant areas emphasized the public function of private actions and lias endeavored to restrict the defenses of unclean liands and in pari delicto to their proper boundaries. Kuehnert and Wohl do not fit within either the strict historical or the prevailing modern interpretations of the unclean hands and in pari delicto doctrines. In eacli case, the plaintiff's only wrong was that lie violated rule $10 \mathrm{~b}-5$ by not disclosing what he believed to be imside infornation. Disallowing the defense in all 10b-5 cases would best serve the purposes behind the securities laws by offering the most protection to the investing public; it would deter the dissemination of tips at the insider level, thus promoting fuller and more reliable disclosures of material information.

Under a no-defense policy each potential violator of rule $10 \mathrm{~b}-5$ would have an enforceable action against his co-conspirator. A nodefense policy would therefore cause every party to liesitate before joming a conspiracy because every other party to the illegal transaction might be a future litigant. With Kuehnert and Wohl as exceptions, the trend in the rapidly developing area of securities regulation lias been toward a liberal interpretation of rule $10 \mathrm{~b}-5$ to compel strict comliance with its requirements. The Supreme Court lias adopted a no-defense policy in antitrust, and the need to adopt a similar no-defense policy im rule $10 \mathrm{~b}-5$ cases is compelling.

Gene G. Harter

Lawrence B. Ordower 